\title{
KOMPETENSI TEKNOLOGI INFORMASI DAN KOMUNIKASI PERGURUAN TINGGI
}

\author{
Harjanto Prabowo \\ Jurusan Manajemen, Fakultas Ekonomi dan Komunikasi, BINUS University \\ Jln. K.H. Syahdan No 9, Palmerah, Jakarta Barat 11480 \\ harprabowo@binus.edu
}

\begin{abstract}
Indonesian universities face internal and external challenges that need to be answered with the proper implementation of competitive strategy, especially for the development of organizational competencies needed in the future. This paper describes the importance of higher education having the competence of information and communication technology (ICT) which is strategic and operational as well as success indicators for the competency.
\end{abstract}

Keywords: competency, information and communication technology, Indonesian universities

\begin{abstract}
ABSTRAK
Perguruan tinggi Indonesia menghadapi tantangan internal dan eksternal yang perlu dijawab dengan implementasi strategi bersaing yang tepat, terutama untuk pengembangan kompetensi organisasi yang diperlukan di masa mendatang. Makalah ini memaparkan pentingnya perguruan tinggi memiliki kompetensi teknologi informasi dan komunikasi (TIK) yang strategis dan operasional serta sebagai indikator sukses untuk kompetensi tersebut.
\end{abstract}

Kata kunci: kompetensi, teknologi informasi dan komunikasi, perguruan tinggi Indonesia 


\section{PENDAHULUAN}

Perguruan tinggi merupakan lembaga pendidikan yang menyelenggarakan pendidikan formal setelah jenjang pendidikan menengah umum, di Indonesia, bentuk perguruan tinggi dapat berupa akademi, politeknik, sekolah tinggi, institut, dan universitas. Upaya pemerintah dalam memberikan rambu-rambu pengelolaan perguruan tinggi sudah banyak dilakukan, baik melalui UU Sistem Pendidikan Nasional, Peraturan Pemerintah, maupun produk hukum lainnya, termasuk juga untuk mendorong adanya kegiatan akreditasi oleh Badan Akrediatasi Nasional yang semakin jelas, terukur, dan teratur.

Keberadaan perguruan tinggi di Indonesia sudah puluhan tahun, namun berdasarkan data/informasi dari berbagai sumber, termasuk penjelasan langsung dari Dirjen Dikti dalam berbagai kesempatan pertemuan dengan pengelola perguruan tinggi, didapatkan beberapa informasi yang sangat menarik untuk dikaji lebih mendalam, yaitu: angka partisipasi kasar perguruan tinggi dan status pekerjaan lulusan perguruan tinggi.

Dalam hal angka partisipasi kasar (APK) sampai tahun 2009, ternyata perguruan tinggi di Indonesia baru mencapai 18,36\%, jauh tertinggal dibandingkan dengan negara Malaysia (32,5\%), Thailand (42,7\%), bahkan untuk negara Korea telah mencapai 91\%. Kondisi ini menunjukkan dua sisi penting, di satu sisi sebagai peluang bagi para pengelola perguruan tinggi untuk meningkatkan daya tampungnya, tetapi di sisi lain juga menunjukkan ancaman akibat ketidakmampuan perguruan tinggi meyakinkan masyarakat yang memerlukan pendidikan tinggi.

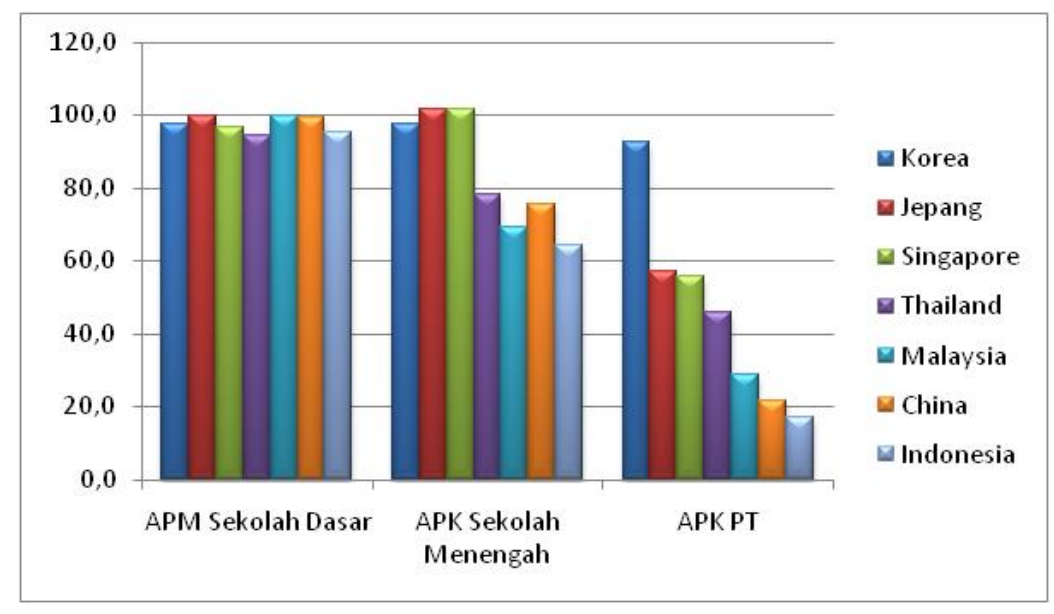

Gambar 1 APK tahun 2009

Sumber: Laporan Dikti

Pemerintah dan masyarakat perlu bekerja sama untuk meningkatkan APK perguruan tinggi, dan itu diperlukan kerja keras dalam menyediakan kapasitas fisik dan kapasitas akademik. Sebagai ilustrasi untuk menaikan angka APK sebesar $1 \%$ yang berarti sekitar 250 ribu tambahan mahasiswa baru tentu diperlukan tambahan kapasitas fisik dan akademik yang harus disiapkan dengan baik. Apabila tambahan kapasitas tersebut dipenuhi melalui pendirian perguruan tinggi baru dengan asumsi masing-masing mempunyai 5 program studi dan kapasitas 50 mahasiswa per prodi, maka akan ada peluang untuk sekitar 1000 perguruan tinggi baru, suatu upaya yang berat bagi pemerintah sebagai regulator. 
Dengan demikian selain pertambahan perguruan tinggi baru, diperlukan juga adanya upaya untuk perguruan tinggi yang ada dalam meningkatkan kapasitas kapasitas akademiknya dan juga untuk meyakinkan masyarakat memilih kuliah di perguruan tinggi. Profil perguruan tinggi Indonesia secara statistik juga dapat diperlihatkan dalam Gambar 2.

\begin{tabular}{|l|r|r|r|}
\hline \multicolumn{1}{|c}{ INDIKATOR } & \multicolumn{1}{c|}{ PTN } & \multicolumn{1}{c|}{ PTS } & TOTAL \\
\hline Jumlah Mahasiswa Total & 907,323 & $2,298,830$ & $3,206,153$ \\
\hline Jumlah Lulusan & 106,026 & 233,522 & 339,548 \\
\hline Jumlah Mahasiswa Baru & 55,225 & 212,864 & 268,089 \\
\hline Jumlah Dosen & 62,084 & 114,527 & 176,611 \\
\hline Jumlah Lembaga PT & 83 & 3,019 & 3,102 \\
\hline Jumlah Program Studi & 3,102 & 12,639 & 15,741 \\
\hline Rasio Mahasiswa/PT & 10,932 & 761 & 1,034 \\
\hline Rasio Mahasiswa/Dosen & 15 & 20 & 18 \\
\hline Rasio Mahasiswa Baru/PT & 665 & 71 & 86 \\
\hline Rasio Dosen/PT & 748 & 38 & 57 \\
Rasio Lulusan/Dosen & 2 & 2 & 2 \\
\hline AEE & 12 & 10 & 11 \\
\hline
\end{tabular}

Gambar 2 Statistik profil perguruan tinggi Indonesia 2010

Sumber: Suharyadi (2012)

Berdasarkan Tabel 2, bebeberapa fenomena menarik yang perlu dicermati, seperti: jumlah PTS hampir 40 kali lipat dari PTN namun dalam rasio mahasiswa per PT untuk PTN hampir 15 kali dari PTS, jumlah mahasiwa baru per PT untuk PTN hampir 10 kali dari PTS. Pemerintah mulai tahun 2011 mulai melakukan alih status dari beberapa perguruan tinggi swasta/milik PEMDA menjadi perguruan tinggi negeri. Upaya ini bisa dimengerti karena adanya usaha untuk meningkatkan APK perguruan tinggi menjadi lebih dari 30\%. Salah satu ukuran penting dari kinerja perguruan tinggi di Indonesia adalah menghasilkan tenaga terdidik yang mampu berkarya di masyarakat, baik sebagai tenaga kerja profesional maupun yang memilih sebagai wirausahawan (pengusaha). Gambar 3 menunjukkan status pekerjaan menurut jenjang pendidikan.

\begin{tabular}{|c|c|c|c|c|c|c|c|}
\hline \multirow{2}{*}{ JENJANG PENDIDIKAN } & \multicolumn{3}{|c|}{ FORMAL } & \multicolumn{3}{|c|}{ INFORMAL } & \multirow{2}{*}{ TOTAL } \\
\hline & Pengusaha & Pekerja & Jumlah & Pengusaha & Pekerja & Jumlah & \\
\hline$\leq \mathrm{SD}$ & $1,440,842$ & $8,805,289$ & $10,246,131$ & $24,376,311$ & $19,554,223$ & $43,930,534$ & $54,176,665$ \\
\hline SLTP & 723,503 & $7,133,310$ & $7,856,813$ & $7,090,311$ & $5,749,481$ & $12,839,792$ & $20,696,605$ \\
\hline SMTA & 829,158 & $8,888,175$ & $9,717,333$ & $4,788,937$ & $2,614,730$ & $7,403,667$ & $17,121,000$ \\
\hline SMK & 333,408 & $5,406,900$ & $5,740,308$ & $2,159,648$ & 952,569 & $3,112,217$ & $8,852,525$ \\
\hline Diploma & 118,260 & $2,607,023$ & $2,725,283$ & 335,859 & 112,374 & 448,233 & $3,173,516$ \\
\hline Universitas & 272,698 & $4,931,193$ & $5,203,891$ & 326,773 & 119,424 & 446,197 & $5,650,088$ \\
\hline TOTAL & $3,717,869$ & $37,771,890$ & $41,489,759$ & $39,077,839$ & $29,102,801$ & $68,180,640$ & $109,670,399$ \\
\hline PERSENTASE & 3.39 & 34.44 & 37.83 & 35.63 & 26.54 & 62.17 & 100.00 \\
\hline
\end{tabular}

Gambar 3 Status pekerjaan menurut jenjang pendidikan Sumber: Suharyadi (2012)

Berdasarkan Tabel 3, terlihat juga adanya fenomena bahwa semakin tinggi pendidikan seseorang maka cenderung untuk lebih memilih jalur pekerja dari pada jalur wirausaha, baik untuk jalur pekerjaan formal maupun informal. Dari 2 hal pokok, yaitu APK perguruan tinggi yang harus ditingkatkan dan status lulusan perguruan tinggi yang cenderung memilih jalur pekerja dari pada wirausaha, merupakan fenomena yang menarik yang harus dipahami dengan benar dan perlu diatasi dengan sungguh-sungguh untuk dapat dijawab dan dicarikan solusi yang lebih baik dan tepat. 
Dari sisi eksternal, ada 2 tantangan bagi perguruan tinggi Indonesia, yaitu globalisasi pendidikan dan dampak kemajuan teknologi informasi dan komunikasi berupa revolusi informasi. Dampak positif globalisasi pendidikan adalah kemudahan belajar di perguruan tinggi luar negeri yang dapat menjadi alternatif utama bagi masyarakat yang ingin mendapatkan pendidikan tinggi yang berkualitas. Puluhan ribu mahasiswa baru dari Indonesia tiap tahun mengisi kursi kuliah di perguruan tinggi luar negeri seperti Malaysia, Singapura, Korea, Cina, Australia, Eropa, dan Amerika. Kemajuan dan kemudahan teknologi informasi dan komunikasi (TIK) memberikan dampak terjadinya revolusi informasi yang luar biasa, terutama untuk membangun kemudahan dalam berkomunikasi dan berkolaborasi. Kondisi ini telah mendorong perguruan tinggi luar negeri menawarkan program $e$ learning atau online learning, walaupun belum banyak diterima oleh masyarakat Indonesia namun perlahan namun pasti akan mengubah pola keputusan masyarakat dalam memilih program pendidikan tinggi. Dua tantangan tersebut semakin menunjukkan bahwa kita harus memahami perubahan peta persaingan dalam menyelenggarakan pendidikan tinggi yang bermutu, sehingga kita tidak menjadi pemain kelas dua atau bahkan tidak diperhitungkan.

Beberapa hal di atas memberikan gambaran kepada kita bahwa: (1) pendidikan tinggi merupakan kebutuhan penting dan akan terus meningkat di masa depan; (2) Indonesia merupakan pasar pendidikan tinggi yang menarik bagi banyak negara; (3) kualitas lulusan perguruan tinggi Indonesia harus mampu bersaing dalam arena global, untuk itu diperlukan upaya yang sungguhsungguh dari semua pihak untuk membangun keunggulan bersaing perguruan tinggi Indonesia.

\section{Kompetensi Organisasi Perguruan Tinggi}

Organisasi perguruan tinggi di Indonesia mempunyai kemiripan satu dengan yang lain karena didasarkan pada peraturan pemerintah yang sama. Secara umum, organisasi yang diterapkan mempunyai tanggung jawab untuk menjalankan fungsi layanan Tri Dharma Perguruan Tinggi, yaitu pendidikan dan pengajaran, penelitian, dan pelayanan kepada masyarakat. Sistem manajemen perguruan tinggi merupakan sistem yang unik, paduan antara kepentingan akademik dan bisnis jasa pendidikan, keduanya saling tarik menarik dan saling memengaruhi kinerja perguruan tinggi.

Di perguruan tinggi, pengelolaan berfokus pada 3 (tiga) kelompok penting, yaitu pengelolaan atas proses, isi (content), dan sumber daya (resources). Tentu saja di luar 3 kelompok di atas, ada pengaruh akan organisasi dan budaya organisasi, nilai-nilai, etos kerja, dan kepemimpinan. Masingmasing kelompok tidak dapat dikelola secara terpisah, namun terpadu dengan memerhatikan arah pengembangan perguruan tinggi masing-masing (visi, misi, tujuan dan sasaran).

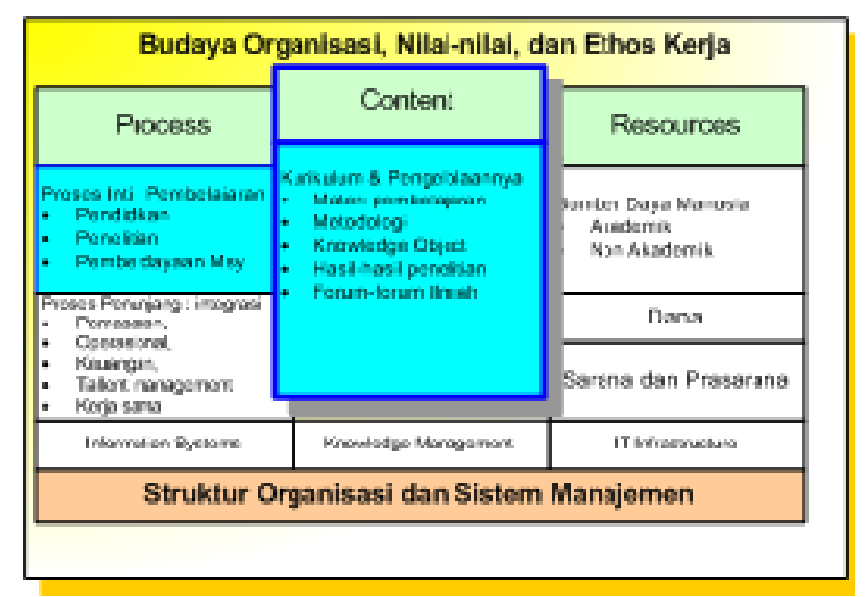

Gambar 4 Pengelolaan Perguruan Tinggi 
Untuk mencapai kinerja yang lebih baik, perguruan tinggi perlu menyusun dan mengimplementasikan strategi yang tepat. Menurut Hunger dan Wheelen, tahapan manajemen strategi dimulai dari analisis kondisi internal dan eksternal, formulasi strategi (penetapan Visi-Misi, obyektif, dan strategi), implementasi startegi, dan evaluasi untuk perbaikan dan peningkatan. Pada dasarnya, penetapan strategi di perguruan tinggi juga untuk membangun kompetensi/kecakapan (capability) yang membuat perguruan tinggi mampu bersaing atau menghadapi persaingan.

Perguruan tinggi sebagai organisasi penyedia jasa pendidikan tinggi haruslah memiliki kompetensi organisasi, antara lain pengembangan program dan sumber daya akademik, layanan operasional akademik, riset dan inovasi, social responsibility, kerja sama strategis, dan pengembangan dan pengelolaan HAKI.

Kompetensi tersebut adalah kompetensi generik yang memang selalu ada di tiap organisasi perguruan tinggi, namun sejalan dengan perkembangan teknologi informasi dan komunikasi serta semakin pentingnya kompetensi yang mampu membuat perbedaan (diferensiasi) terhadap organisasi yang lain, maka diperlukan kompetensi organisasi perguruan tinggi yang baru, seperti kompetensi teknologi informasi dan komunikasi.

\section{Teknologi Informasi dan Komunikasi}

Teknologi informasi dan komunikasi (TIK) terdiri atas 3 bagian utama, sering disebut dengan 3C, yaitu computer, content, dan communication. Teknologi computer terdiri atas hardware dan software, sedangkan teknologi content mencakup teknologi dan system database dan multimedia. Untuk teknologi communication mencakup teknologi jaringan data, Internet, dan berkembang juga ke teknologi mobile communication.

TIK berkembang dengan sangat cepat dan membawa banyak perubahan dalam masyarakat, baik pelaku bisnis, pemerintah, sosial, maupun masyarakat awam. Perkembangan yang cepat memberikan situasi yang saya sebut dengan revolusi informasi.

Tahun-tahun terakhir ini ditandai dengan munculnya aplikasi-aplikasi Social Networking yang makin memperluas definisi jejaring/bersosialisasi dengan memanfaatkan dunia maya. Aplikasiaplikasi semacam facebook, Friendster, Myspace telah memberikan peluang yang luar biasa untuk setiap individu dapat berkomunikasi dan membentuk komunitas online dan siap menggantikan pola lama seperti penggunaan mailing-list. Platform utama dari segala macam aplikasi Web 2.0 adalah pola kolaborasi ataupun sharing.

Kebiasaan dan sifat generasi baru yang lebih terbuka (Net Generation-Don Tapscott, atau kini banyak orang menyebut Y Generation) telah menjadi fondasi utama dari dasar-dasar aplikasi Web 2.0 di Internet. Ciri khas mereka yang terbuka untuk kolaborasi, kecakapan menggunakan teknologi tinggi, telah membawa pengaruh besar dalam penciptaan aplikasi-aplikasi social networking.

Fenomena " $e$ " dalam beberapa tahun belakangan ini telah bergeser ke fenomena " $m$ ". Penggunaan mobile device telah memperlebar spekrum pilihan perangkat pendukung dalam penciptaan serta penyebaran informasi, melalui konvergensi teknologi data dan suara, kini perangkat bergerak (mobile devices) smartphone dengan berbagai merek telah memberi keleluasaan bagi pemakainya untuk berkontribusi dan berkolaborasi. E-mail yang tadinya menjadi bentuk paling dasar untuk menandai identitas unik seseorang dan eksistensinya di Internet, kini mulai tidak ditanyakan dan berganti dengan account facebook ataupun LinkedIn.

Wikipedia memberikan kesempatan bagi volunteer di seluruh dunia untuk berkolaborasi menulis ensiklopedia terbesar di dunia yang benar-benar hidup karena dapat berubah setiap waktu. 
Republik Facebook dengan lebih dari 200 juta pemakai di seluruh dunia telah memberi pengaruh yang tinggi terhadap perilaku hidup para member-nya sehari-hari. Namun perlu disadari bahwa revolusi informasi yang terjadi di atas belum banyak diserap dalam lingkup organisasi perguruan tinggi Indonesia untuk mentransformasi proses bisnis dan cara kerja yang telah usang. Jadi perguruan tinggi seperti sebuah dunia lain yang tidak bisa di-connect dengan semua perangkat dan piranti TIK milik individu yang ada di dalam maupuan di luar perguruan tinggi.

Di perguruan tinggi, TIK dapat digunakan dalam banyak kegiatan, mulai dari automasi kegiatan administrasi dan layanan akademik sampai dengan kegiatan pembelajaran. Menurut Indrajit dan Djokopranoto (2006), ada 7 peran TIK di institusi pendidikan, yaitu sebagai (1) source of knowledge, (2) learning tools and devices, (3) skill and competencies, (4) transformation enables, (5) integrated administration system, (6) decision support system, dan (7) core infrastructure. Tidak semua peran tersebut diimplementasikan di perguruan tinggi, bergantung dari komitmen perguruan tinggi, terutama jika terkait dengan penyediaan dana investasi. Bentuk lain yang menggambarkan peran TIK dalam perguruan tinggi dapat dilihat dalam Gambar 2 di bawah ini.

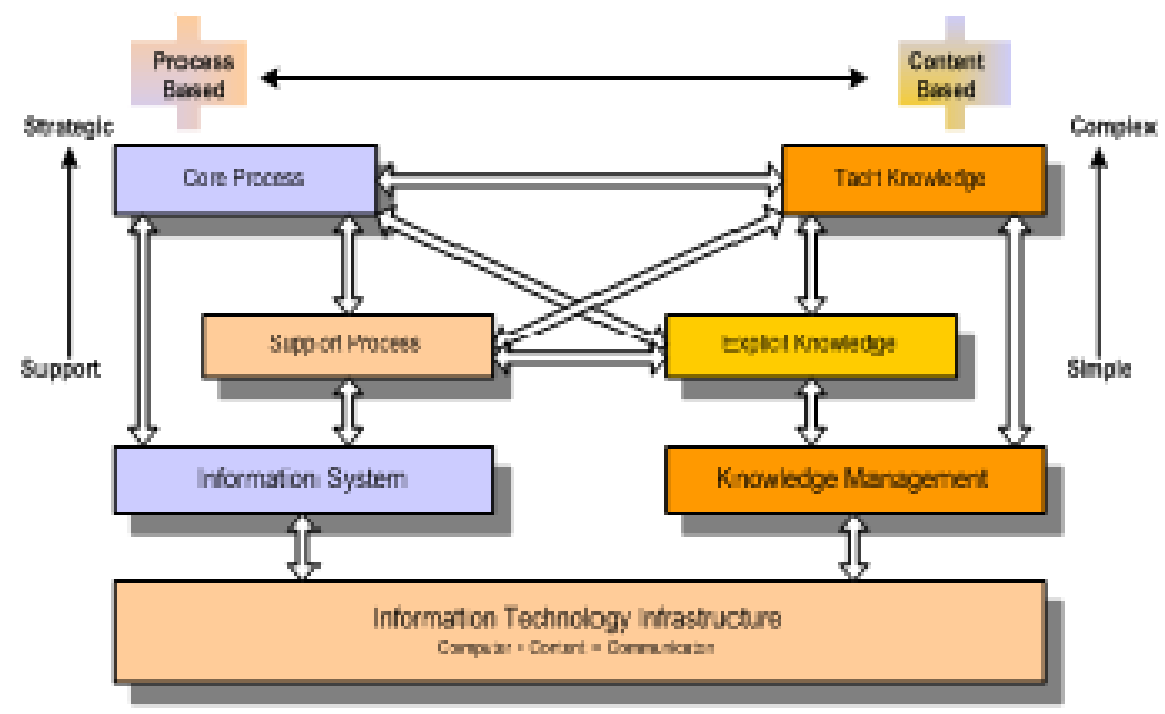

Gambar 5 Peran TIK di Perguruan Tinggi

Gambar 5 menunjukkan bahwa penggunaan infrastruktur TIK yang mendukung kemajuan sistem informasi dapat digunakan di perguruan tinggi untuk kegiatan yang bersifat support seperti administrasi, dan layanan, maupun untuk kegiatan yang bersifat core bisnis seperti kegiatan pembelajaran. Di sisi yang lain, kemajuan TIK juga mendorong implementasi knowledge management, sehingga perguruan tinggi tidak menjadi organisasi yang kering namun terus berkembang dengan menggunakan knowledge sebagai salah satu kapitalnya. Kegiatan pembelajaran adalah kegiatan utama di perguruan tinggi, peluang dan pengaruh pemanfaatan TIK dalam kegiatan pembelajaran dapat dilihat dalam Gambar 6. 


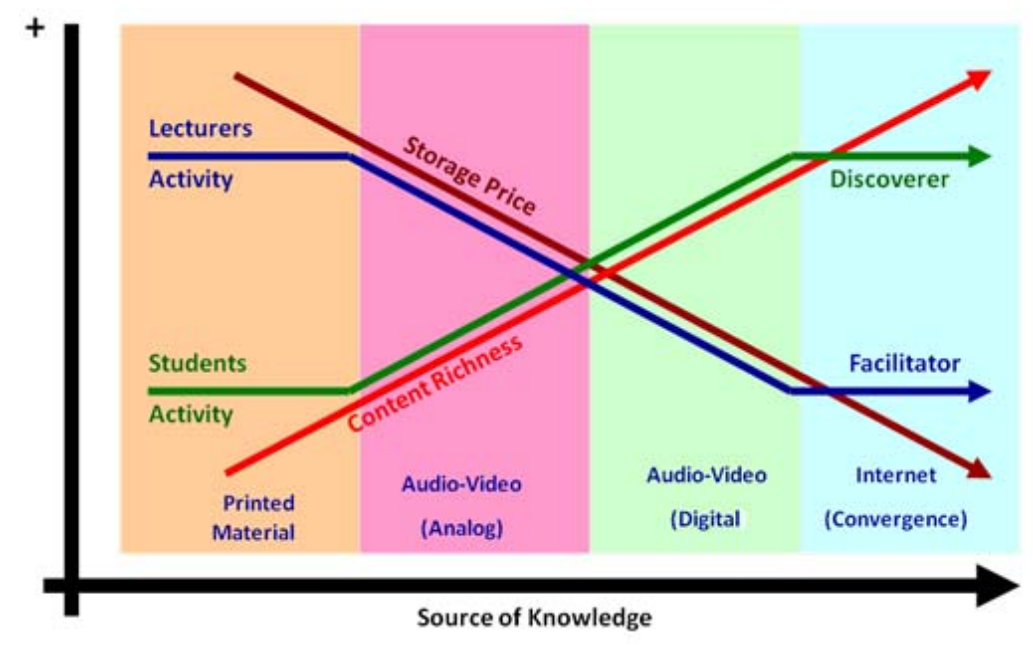

Gambar 6 TIK sebagai Source of Knowledge

Gambar 6 menunjukkan bahwa pemanfaatan TIK sebagai Source of Knowledge memberikan beberapa peluang, yaitu kemudahan dalam pengayaan konten yang didukung dengan biaya storage yang makin murah, tetapi sekaligus mendorong perubahan yang besar atas peran dosen (dari lecturer center menjadi facilitator) yang mendorong terbentuknya student center learning.

\section{Kompetensi Teknologi Informasi dan Komunikasi Perguruan Tinggi}

Walaupun sudah banyak perguruan tinggi menyadari akan peran dan pentingnya TIK, namun tidak mudah dan tidak semua perguruan tinggi sukses dalam mengimplementasikannya. Sebagian besar perguruan tinggi menghabiskan dana untuk investasi pada peralatan dan pengembangan aplikasi, namun manfaat besar yang dijanjikan dan diharapkan pada awal implementasi hanya menjadi harapan dan juga menimbulkan ketidakpuasan.

Salah satu penyebab utama kegagalan adalah perguruan tinggi menempatkan teknologi informasi hanya sebagai sumber daya (resources) yang berarti sesuatu yang perlu diadakan dan bersifat fisik. Teknologi informasi sebagai sumber daya organisasi tentu berbeda maknanya dengan teknologi informasi sebagai kompetensi organisasi karena memiliki sumber daya, tidak otomatis memiliki kompetensi.

Budiman Sanusi, Direktur Psikologi dan Pengembangan Sumber Daya Manusia (PPSDM), mengatakan bahwa kompetensi adalah keseluruhan pengetahuan, keterampilan, perilaku, dan sikap yang ditampilkan oleh orang-orang yang sukses/berhasil dalam mengerjakan suatu tugas dengan prestasi kerja yang optimal.

Steven Moulton mengatakan bahwa kompetensi organisasi bisa didefinisikan sebagai kemampuan teknikal yang membedakan perusahaan dengan pesaing, sedangkan kompetensi individu bisa didefinisikan sebagai kombinasi pengetahuan, keahlian, dan kebisaan yang memengaruhi kinerjanya. Jadi, secara umum, kompetensi organisasi pada dasarnya adalah kemampuan/skill untuk menggunakan sumber daya yang dimiliki secara tepat agar dapat melakukan sesuatu sesuai dengan tujuan yang diharapkan.

Yang dimaksud kompetensi TIK perguruan tinggi adalah kemampuan atau skill yang harus dimiliki organisasi perguruan tinggi untuk menggunakan sumber daya TIK dalam melakukan kegiatan di perguruan tinggi sesuai dengan tujuan perguruan tinggi tersebut. Kompetensi TIK di perguruan 
tinggi dapat dikelompokkan dalam dua kategori, yaitu kompetesi strategis TIK dan kompetensi operasional TIK. Kompetensi strategis TIK perguruan tinggi adalah kemampuan perguruan tinggi menggunakan TIK untuk kegiatan yang bertujuan meningkatkan daya saing dan keberlanjutkan organisasi perguruan tinggi. Sebagai contoh adalah kemampuan untuk mengolah informasi dan knowledge dalam menyusun strategi pengembangan organisasi, mengembangkan produk pendidikan, dan juga untuk memperluas daerah geografis asal calon mahasiswa yang potensi. Kompetensi strategis TIK ini haruslah dimiliki oleh perguruan tinggi yang ingin berkembang dan memiliki daya saing tinggi. Kompetensi operasional TIK perguruan tinggi adalah kemampuan perguruan tinggi menggunakan TIK untuk kegiatan yang bertujuan untuk meningkatkan efektifitas dan atau efisiensi operasional perguruan tinggi. Sebagai contoh adalah kemampuan untuk menggunakan TIK dalam layanan administrasi dan keuangan, monitoring kegiatan pembelajaran, monitoring penggunaan sumber daya lain (efiseinsi penggunaan air, listrik, dan lainnya). Kompetesi operasional TIK ini harus dimiliki oleh perguruan tinggi yang ingin menjaga dan meningkatkan kualitas layanan kepada stakeholder melalui kegiatan rutin/operasional yang dilakukannya. Indikator sukses kompetensi TIK perguruan tinggi tentu berbeda dengan indikator sukses TIK sebagai sumber daya organisasi. Tabel 1 menunjukkan indikator sukses untuk kompetensi TIK dan sumber daya TIK di perguruan tinggi.

Tabel 1 Indikator sumber daya dan kompetensi TIK perguruan tinggi

\begin{tabular}{|c|c|}
\hline Indikator Sumberdaya TIK & Indikator Kompetensi TIK \\
\hline Rasio komputer per mhs & Jumlah keputusan strategis berbasis TIK \\
\hline Rasio bandwidth internet per mhs & Jumlah program / produk layanan berbasis TIK \\
\hline Jumlah aplikasi yang digunakan & $\begin{array}{l}\text { Jumlah kegiatan operasional yang berbasis TIK (otomasi } \\
\text { dan semi otomasi) }\end{array}$ \\
\hline $\begin{array}{l}\text { Jumlah aplikasi baru yang } \\
\text { diimplementasikan }\end{array}$ & $\begin{array}{l}\text { Jumlah bahan ajar yang dikembangkan dengan } \\
\text { menggunakan TIK }\end{array}$ \\
\hline Jumlah tenaga TIK & $\begin{array}{l}\text { Kenaikan skor kemampuan TIK yg dimiliki mahasiswa } \\
\text { dan alumni }\end{array}$ \\
\hline $\begin{array}{l}\text { Persentase Budget TIK terhadap total } \\
\text { budget }\end{array}$ & Kenaikan skor kemampuan TIK yg dimiliki staff \\
\hline Ukuran lain yang bersifat sumber daya & Ukuran lainnya yang bersifat kompetensi \\
\hline
\end{tabular}

Dengan memerhatikan perbedaan indikator di atas, maka perguruan tinggi perlu menyusun strategi untuk tidak hanya untuk meningkatkan sumber daya TIK, tetapi juga kompetensi TIK.

\section{PENUTUP}

Perguruan tinggi di Indonesia menghadapi tantangan internal dan eksternal, kinerja yang ada sekarang menunjukkan bahwa perguruan tinggi di Indonesia perlu melakukan upaya-upaya yang berkesinambungan untuk meningkatkan daya saing. Strategi peningkatan daya saing pada dasarnya adalah untuk meningkatkan kompetensi/kapabilitas organsiasi perguruan tinggi agar mampu memberikan layanan pendidikan dan berdaya saing tinggi di masyarakat. Selain kompetensi yang bersifat generik, organisasi perguruan tinggi perlu memiliki kompetensi Teknologi Informasi dan Komunikasi (TIK). Yang selama ini, TIK hanya dianggap sebagai salah satu sumber daya saja. 


\section{DAFTAR PUSTAKA}

Indrajit, R. E., \& Djokopranoto, R. (2006). Manajemen perguruan tinggi modern. Yogyakarta: Andi.

Suharyadi, H. (2012). Penguatan peranan APTISI dalam peningkatan SDM unggul dan terciptanya 1,000,000 wirausahawan baru. Makalah Presentasi Rapat APTISI Padang 